\title{
Mineral Composition of Lettuce Grown in Hydroponic System With Wastewater
}

\author{
Josilda de França Xavier ${ }^{1}$, Carlos Alberto Vieira de Azevedo 2 , Marcia Rejane de Q. A. Azevedo ${ }^{3}$, \\ José Emídio de Albuquerque Junior ${ }^{3} \&$ João Paulo de Oliveira Simões ${ }^{4}$ \\ ${ }^{1}$ Empresa Estadual de Pesquisa Agropecuária da Paraíba S. A., Estação Experimental de Lagoa Seca, Brazil \\ ${ }^{2}$ Universidade Federal de Campina Grande, Campina Grande, PB, Brazil \\ ${ }^{3}$ Universidade Estadual da Paraíba, Campus-II, Lagoa Seca, PB, Brazil \\ ${ }^{4}$ Instituto Nacional do Semiárido, Campina Grande, PB, Brazil \\ Correspondence: Josilda de França Xavier, Empresa Estadual de Pesquisa Agropecuária da Paraíba S. A., \\ Estação Experimental de Lagoa Seca, Brazil. E-mail: josildaxavier@yahoo.com.br
}

\author{
Received: April 1, $2018 \quad$ Accepted: May 2, $2018 \quad$ Online Published: June 15, 2018 \\ doi:10.5539/jas.v10n7p317 URL: https://doi.org/10.5539/jas.v10n7p317
}

\begin{abstract}
The use of treated effluents is not a new practice in agriculture, however, the optimization of wastewater was given with mineral fertilizers to grow lettuce in a hydroponic system, subject that is still barely studied. The objective of this study was to evaluate the mineral composition of three lettuce cultivars (Verônica, Vanda and Thais) in a hydroponic system using wastewater, well water and optimized nutrient solutions. The plants was grown in seven nutrient solutions, as $\mathrm{S}_{1}=$ Furlani solution; $\mathrm{S}_{2}=$ domestic wastewater; $\mathrm{S}_{3}=$ optimized domestic wastewater; $\mathrm{S}_{4}=$ well water; $\mathrm{S}_{5}=$ optimized well water; $\mathrm{S}_{6}=$ wastewater UASB and $\mathrm{S}_{7}=$ optimized UASB wastewater and the sub-plot for three lettuce cultivars. It was verified that the treatments $S_{2}, S_{4}$ and $S_{6}$ when compared with the respective optimized solutions $S_{3}, S_{5}$ and $S_{7}$ presented lower levels of nitrogen, potassium, calcium, zinc, copper and manganese in the two experiments. Same behavior was not observed for phosphorus and sodium. As for the cultivars, they presented, regardless of the experiment, mineral composition similar to each other when the same nutrient solution was used.
\end{abstract}

Keywords: water reuse, Lactuca sativa $\mathrm{L}$.

\section{Introduction}

Lettuce (Lactuca sativa L.) is the most widespread leafy vegetable currently cultivated in almost all countries. Because of its ease of cultivation, low production cost and ease of commercialization, lettuce is grown for both commercial and subsistence purposes (Correia, 2013). In Brazil, crisp-type lettuce cultivation leads the market with $70 \%$ of production, while the Iceberg type owns $15 \%$, lettuce $(10 \%$, and the others correspond to $5 \%$ of the market (Sala \& Costa, 2012) , and occupies an area of approximately 35.000 hectares being as much by the intensive production, as by familiar producers (Sousa et al., 2014).

Lettuce is produced in hydroponic solution has advantage comparing with that produced in the open field, because the leaves are not irrigated, reducing the incidence of diseases and also because the water used in the nutrient solution has a simpler quality control (Lopes, Duval, \& Reis, 2010). Some studies developed with NFT technique ("Nutrient Film Technique"), hydroponic system or in culture with inert substrate has been using wastewater mainly for lettuce. In hydroponics, plants receive a balanced nutrient solution containing water and all essential nutrients for plant development (Santos et al., 2012).

With the use of the treated sewage it is possible to make possible a new source of water and nutrients available for application in agriculture, even during drought periods (Shaer Barbosa et al., 2014). On the other hand, the safety of reuse of wastewater for irrigation purposes is a matter of caution. In general, the current regulations for the reuse of treated sewage specify the microbiological quality standards, considering the minimum treatments required for the effluents, the type of crop to be irrigated and the irrigation methods used.

The interest in using treated wastewater in irrigation is the objective of more recent studies (Bonini et al., 2014), and it has become an attractive option because it reduces the contamination by the direct discharge of sewage in 
the water bodies, improving the potability conditions, allowing a more rational use of water resources, being an alternative source of available water (Martínez et al., 2013). Thus, the use of treated sewage in agriculture can become an important tool in water management.

It should be noted that the domestic sewage effluent contains high concentrations of macro and micronutrients. The availability of this material for the soil in the form of fertirrigation can supply part of the nutritional needs of the crops, reduce the fertilizer costs avoid the disposal in water bodies, besides allowing better use by plants, due to the installment of fertilization(Souza et al., 2012; Andrade Filho et al., 2013). When assessing the agricultural potential of effluent domestic sewage, Carr et al. (2011) found that on average the effluent used on farms in Jordan replaces up to $75 \%$ of fertilizer needs. Many wastewater exhibit high concentrations of nitrogen, phosphorus and potassium and organic material (Oliveira, 2012). On the other hand, the excess of some elements in the effluent can also reduce crop productivity (Hanjraa et al, 2012).

In this context the use of wastewater in addition to minimizing environmental problems can reduce the use of mineral fertilizers and clean water in irrigated agriculture in semiarid regions. This reduction in the use of mineral fertilizers is possible due to the high concentration of nutrients in wastewater (Varallo et al., 2012), since it is handled judiciously (Matos et al., 2013). Giving this conjecture, the plants play a significant role, extracting macro and micronutrients provided by the wastewater, necessary for the growth avoiding accumulation, the consequent salinization of the soil and the contamination of surface and groundwater (Ribeiro et al., 2009).

The use of treated wastewater in agriculture is essential, not only to serve as an extra source of water, but also as a source of nutrients for crops. In this context, it was objectified with this work, evaluate the mineral composition of three lettuce cultivars (Verônica, Vanda and Thais) in a hydroponic system using wastewater, well water and optimized nutrient solutions.

\section{Material and Methods}

This experiment was conducted in a hydroponic system using Nutrient Film Technique (NFT), in protected environment, a Greenhouse of the State University of Paraíba, Campus II, in the municipality of Lagoa Seca-PB.

Regarding the experimental design: were used randomized blocks with treatments arranged in subdivided plots, with three replications. The plots were the hydroponic solutions with conductivity of $1.7 \mathrm{dS} \mathrm{m}^{-1} ; \mathrm{S}_{1}=$ Furlani solution; $\mathrm{S}_{2}=$ domestic wastewater; $\mathrm{S}_{3}=$ optimized domestic wastewater; $\mathrm{S}_{4}=$ well water; $\mathrm{S}_{5}=$ optimized well water; $\mathrm{S}_{6}=$ wastewater solution from the Upflow Anaerobic Sludge Blanket (UASB) reactor and $\mathrm{S}_{7}=$ optimized wastewater solution from the UASB reactor and the subplot for three lettuce cultivars; Verônica, Vanda e and Thais. Each subplot was composed of six plants (two plants of each cultivar) with spacing of $0.30 \mathrm{~m} \times 0.30 \mathrm{~m}$.

The seeds of lettuce curly cultivars were sowed in phenolic foam using a table for germination. After emergence of the seedling (ES), the supply water used in irrigation was gradually replaced by nutrient solutions $(33.33 \%$, $66.66 \%$ and $100 \%$ every four days). After 25 days of ES, the seedlings were transplanted to the definitive profiles (the gutters used for the hydroponic system.

Optimized nutrient solutions were formulated with reference to the nutritional solution of Furlani 1999 (Table 1). 
Table 1. Quantitative of the mineral fertilizers used in the preparation of mineral nutritive solutions

\begin{tabular}{|c|c|}
\hline \multicolumn{2}{|l|}{ Solution } \\
\hline Mineral salts & Furlani \\
\hline \multicolumn{2}{|c|}{ 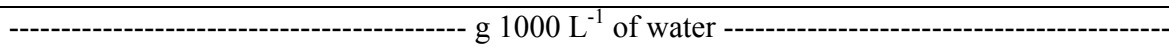 } \\
\hline $\mathrm{Ca}\left(\mathrm{NO}_{3}\right)_{2} \cdot 6 \mathrm{H}_{2} \mathrm{O}$ & 1000 \\
\hline MAP & 150 \\
\hline DAP & - \\
\hline $\mathrm{H}_{2} \mathrm{PO}_{4}$ & - \\
\hline $\mathrm{KH}_{2} \mathrm{PO}_{4}$ & - \\
\hline $\mathrm{KCl}$ & 150 \\
\hline $\mathrm{KNO}_{3}$ & 600 \\
\hline $\mathrm{MgSO}_{4} \cdot 7 \mathrm{H}_{2} \mathrm{O}$ & 250 \\
\hline $\mathrm{MnCl} . \mathrm{H}_{2} \mathrm{O}$ & 2.34 \\
\hline $\mathrm{Mn} \mathrm{SO}_{4} \cdot \mathrm{H}_{2} \mathrm{O}$ & - \\
\hline $\mathrm{ZnSO}_{4} \cdot 7 \mathrm{H}_{2} \mathrm{O}$ & 0.88 \\
\hline $\mathrm{CuSO}_{4} \cdot 5 \mathrm{H}_{2} \mathrm{O}$ & 0.2 \\
\hline $\mathrm{H}_{3} \mathrm{BO}_{3}$ & 2.04 \\
\hline $\mathrm{Na}_{2} \mathrm{MoO}_{4} \cdot 2 \mathrm{H}_{2} \mathrm{O}$ & 0.26 \\
\hline Fe-EDTA & $1000 \mathrm{~mL}$ \\
\hline
\end{tabular}

Note. $\mathrm{Ca}\left(\mathrm{NO}_{3}\right)_{2} \cdot 6 \mathrm{H}_{2} \mathrm{O}$ : Calcium nitrate; MAP: Monoammonium phosphate; DAP: Diammonium phosphate; $\mathrm{H}_{2} \mathrm{PO}_{4}$ : Phosphoric acid; $\mathrm{KH}_{2} \mathrm{PO}_{4}$ : Phosphate monopotassium; $\mathrm{KCl}$ : Potassium chloride; $\mathrm{KNO}_{3}$ : Potassium nitrate; $\mathrm{MgSO}_{4} \cdot 7 \mathrm{H}_{2} \mathrm{O}$ : Magnesium sulfate; $\mathrm{MnCl} \cdot \mathrm{H}_{2}$ : Manganese chloride; $\mathrm{MnSO}_{4} \cdot \mathrm{H}_{2} \mathrm{O}$ : Manganese sulfate; $\mathrm{ZnSO}_{4} \cdot 7 \mathrm{H}_{2} \mathrm{O}$ : Zinc sulfate; $\mathrm{CuSO}_{4} \cdot 7 \mathrm{H}_{2} \mathrm{O}$ : Copper sulfate; $\mathrm{H}_{3} \mathrm{BO}_{3}$ : Boric acid $\mathrm{Na}_{2} \mathrm{MoO}_{4} \cdot 2 \mathrm{H}_{2} \mathrm{O}$ : Ammonium molybdate; Fe-EDTA: Iron Ethylenediamine tetraacetic acid.

The water used in the experiment came from rainwater stored in cistern (for the solution $\mathrm{S}_{1}$ ), the raw sewage of the city of Lagoa Seca-PB, tubular well water from the rural area of the municipality Lagoa Seca-PB and wastewater from the UASB reactor of the Experimental Station of Biological Treatment of Sanitary Sewers (EXTRABES) Campina Grande-PB. They were sent for physical-chemical analysis in the Laboratory of Irrigation and Salinity (LIS/DEAg/UFCG), the physical-chemical characterization of the waters used in this work is shown in Table 2.

Table 2. Physical-chemical characterization of waters used in hydroponic irrigation

\begin{tabular}{|c|c|c|c|c|c|c|}
\hline \multirow{2}{*}{ Determinations } & \multicolumn{3}{|c|}{$1^{\circ}$ Experiment } & \multicolumn{3}{|c|}{$2^{\circ}$ Experiment } \\
\hline & Well water & Raw sewage & Extrabes & Well water & Raw sewage & Extrabes \\
\hline $\mathrm{pH}$ & 7.7 & 7.4 & 7.2 & 7.4 & 8.0 & 8.2 \\
\hline Electric conductivity $\left(\mathrm{dS} \mathrm{m}^{-1}\right)$ & 0.957 & 2.133 & 2.502 & 1.002 & 2.368 & 2.409 \\
\hline Calcium $\left(\mathrm{mmol}_{\mathrm{c}} / \mathrm{L}\right)$ & 3.62 & 3.98 & 5.98 & 1.98 & 4.55 & 2.40 \\
\hline Magnesium $\left(\mathrm{mmol}_{\mathrm{C}} / \mathrm{L}\right)$ & 0.75 & 3.47 & 3.42 & 1.88 & 2.25 & 4.60 \\
\hline Sodium $\left(\mathrm{mmol}_{\mathrm{c}} / \mathrm{L}\right)$ & 3.94 & 10.57 & 15.55 & 4.69 & 12.32 & 13.48 \\
\hline Potassium $\left(\mathrm{mmol}_{\mathrm{c}} / \mathrm{L}\right)$ & 0.38 & 1.26 & 0.01 & 0.41 & 1.39 & 0.89 \\
\hline Chlorides $\left(\mathrm{mmol}_{\mathrm{c}} / \mathrm{L}\right)$ & 6.42 & 9.99 & 23.23 & 6.43 & 9.28 & 12.76 \\
\hline Carbonates $\left(\mathrm{mmol}_{\mathrm{c}} / \mathrm{L}\right)$ & 0.00 & 0.00 & 0.00 & 0.00 & 0.00 & 0.00 \\
\hline Bicarbonate $\left(\mathrm{mmol}_{\mathrm{c}} / \mathrm{L}\right)$ & 1.31 & 10.95 & 3.25 & 1.26 & 13.98 & 9.66 \\
\hline Total phosphorus $\left(\mathrm{mg} \mathrm{L}^{-1}\right)$ & 4.51 & 29.30 & 4.14 & 1.83 & 19.02 & 13.41 \\
\hline Nitrate $\left(\mathrm{NO}_{3}^{-}\right)(\mathrm{mg} \mathrm{L})$ & 16.73 & 0.00 & 1.03 & 15.23 & 0.00 & 0.00 \\
\hline Ammonia $\left(\mathrm{NH}_{3}\right)\left(\mathrm{mg} \mathrm{L}^{-1}\right)$ & 0.61 & 1.27 & 58.6 & 0.11 & 1.19 & 52.46 \\
\hline Sodium adsorption ratio & 2.57 & 6.93 & 8.53 & 3.02 & 9.59 & 8.15 \\
\hline Water class for irrigation & $\mathrm{C}_{2} \mathrm{~S}_{1} \mathrm{~T}_{2}$ & $\mathrm{C}_{3} \mathrm{~S}_{1} \mathrm{~T}_{3}$ & $\mathrm{C}_{3} \mathrm{~S}_{1} \mathrm{~T}_{3}$ & $\mathrm{C}_{2} \mathrm{~S}_{2} \mathrm{~T}_{2}$ & $\mathrm{C}_{3} \mathrm{~S}_{1} \mathrm{~T}_{3}$ & $\mathrm{C}_{3} \mathrm{~S}_{1} \mathrm{~T}_{3}$ \\
\hline
\end{tabular}

Optimized nutrient solutions $\mathrm{S}_{3}, \mathrm{~S}_{5}$ and $\mathrm{S}_{7}$ were prepared according to methodology proposed by Monteiro Filho et al. (2014), in order to present chemical composition similar to the nutritional mineral solution of Furlani (1995). The amount of ingredients necessary for the preparation of such solutions is described in Table 3. 
Table 3. Quantitative of the ingredients used in the preparation for the optimized nutrient solutions from the physicochemical characterization of the waters used in hydroponic irrigation

\begin{tabular}{|c|c|c|c|}
\hline \multirow{2}{*}{ Ingredients } & \multicolumn{3}{|c|}{ Quantity of ingredients used to prepare optimized solutions } \\
\hline & $\mathrm{S}_{3}$ & $\mathrm{~S}_{5}$ & $\mathrm{~S}_{7}$ \\
\hline EXTRABES & $199.58 \mathrm{~L}$ & - & - \\
\hline Well water & - & $199.64 \mathrm{~L}$ & - \\
\hline Raw sewage & - & - & $199.64 \mathrm{~L}$ \\
\hline Ammonium sulfate: $\left(\mathrm{NH}_{4}\right)_{2} \mathrm{SO}_{4}$ & $23.66 \mathrm{~g}$ & $22.31 \mathrm{~g}$ & $25.09 \mathrm{~g}$ \\
\hline Calcium nitrate: $\left(\mathrm{NO}_{3}\right)_{2}$ & $238.24 \mathrm{~g}$ & $237.53 \mathrm{~g}$ & $193.54 \mathrm{~g}$ \\
\hline Potassium nitrate: $\mathrm{KNO}_{3}$ & $84.06 \mathrm{~g}$ & $80.95 \mathrm{~g}$ & $121.74 \mathrm{~g}$ \\
\hline Potassium chloride: $\mathrm{KCl}$ & $46.32 \mathrm{~g}$ & $50.04 \mathrm{~g}$ & $0.00 \mathrm{~g}$ \\
\hline Copper Sulfate: $\mathrm{CuSO}_{4}$ & $0.04 \mathrm{~g}$ & $0.04 \mathrm{~g}$ & $0.04 \mathrm{~g}$ \\
\hline Zinc sulfate: $\mathrm{ZnSO}_{4}$ & $0.11 \mathrm{~g}$ & $0.11 \mathrm{~g}$ & $0.11 \mathrm{~g}$ \\
\hline Manganese Sulfate: $\mathrm{MnSo}_{4}$ & $0.49 \mathrm{~g}$ & $0.49 \mathrm{~g}$ & $0.49 \mathrm{~g}$ \\
\hline Magnesium sulphate: $\mathrm{MgSO}_{4}$ & $2.19 \mathrm{~g}$ & $4.27 \mathrm{~g}$ & $0.00 \mathrm{~g}$ \\
\hline Ammonium molybdate: $\left(\mathrm{NH}_{4}\right)_{6} \mathrm{Mo}_{7} \mathrm{O}_{24}$ & $0.06 \mathrm{~g}$ & $0.06 \mathrm{~g}$ & $0.06 \mathrm{~g}$ \\
\hline Boric acid: $\mathrm{H}_{3} \mathrm{BO}_{3}$ & $0.42 \mathrm{~g}$ & $0.42 \mathrm{~g}$ & $0.42 \mathrm{~g}$ \\
\hline Monoammonium phosphate: MAP & $3.14 \mathrm{~g}$ & $10.43 \mathrm{~g}$ & $5.14 \mathrm{~g}$ \\
\hline Iron sulphate: $\mathrm{FeSO}_{4}$ & $12.05 \mathrm{~g}$ & $12.05 \mathrm{~g}$ & $12.05 \mathrm{~g}$ \\
\hline
\end{tabular}

The management of the nutritive solutions were performed daily through the replenishment of the water consumed, along with the monitoring of the electrical conductivity (EC) and $\mathrm{pH}$ keeping it close to neutrality, with the use of a solution of $\mathrm{NaOH}$ ou HCL $\left(1 \mathrm{~mol} \mathrm{~L}^{-1}\right)$.

During the conduction of the experiment the $\mathrm{S}_{1}$ and optimized solutions were calibrated by conducting electrical conductivity readings (EC) and using a portable conductivity meter, in addition to a single parameter. EC was maintained with approximately $1.7 \pm 0.3 \mathrm{dS} \mathrm{cm}^{-1}$ and the $\mathrm{pH}$ between $6.5 \pm 0.5$. Nutrient solutions were renewed every seven days.

For the analysis of the mineral composition of the plant tissue of cultivars of crisp lettuce, composite samples were prepared considering six plants/plot, depending on the cultivars and solutions.

For the analysis of the mineral composition of the plant tissue of cultivars of crisp lettuce, composite samples were prepared considering six plants/plot depending on the cultivars and solutions. The nitrogen was analyzed by means of distillation in Kjeldhal Microdistiller, phosphorus spectrophotometry by Visible Ultraviolet Spectrophotometry (UV-VIS), Sodium and potassium using flame photometer and for the other minerals the readings were made through atomic absorption spectrometry (Agilent Technologies 200 series AA). The analyzes were carried out in the Laboratory of Analysis of Soil, Water and Plant of the Agricultural Research Company of Rio Grande do Norte S/A-EMPARN, determined through the methodology proposed by Embrapa (1999).

\section{Results and Discussion}

During the cultivation no symptoms of mineral deficiency were observed in lettuce plants. One of the benefits of the NFT system for plants is the passage of the nutrient solution only through the root zone, without causing wetting of the leaves. Macro and micronutrient contents of aerial part of cultivars of curly lettuce Thaís, Vanda e Verônica the 30 days after transplant (DAT) in the first experiment and the 35 days after transplant (DAT) in the second experiment submitted to the different treatments are presented in the following figures. 


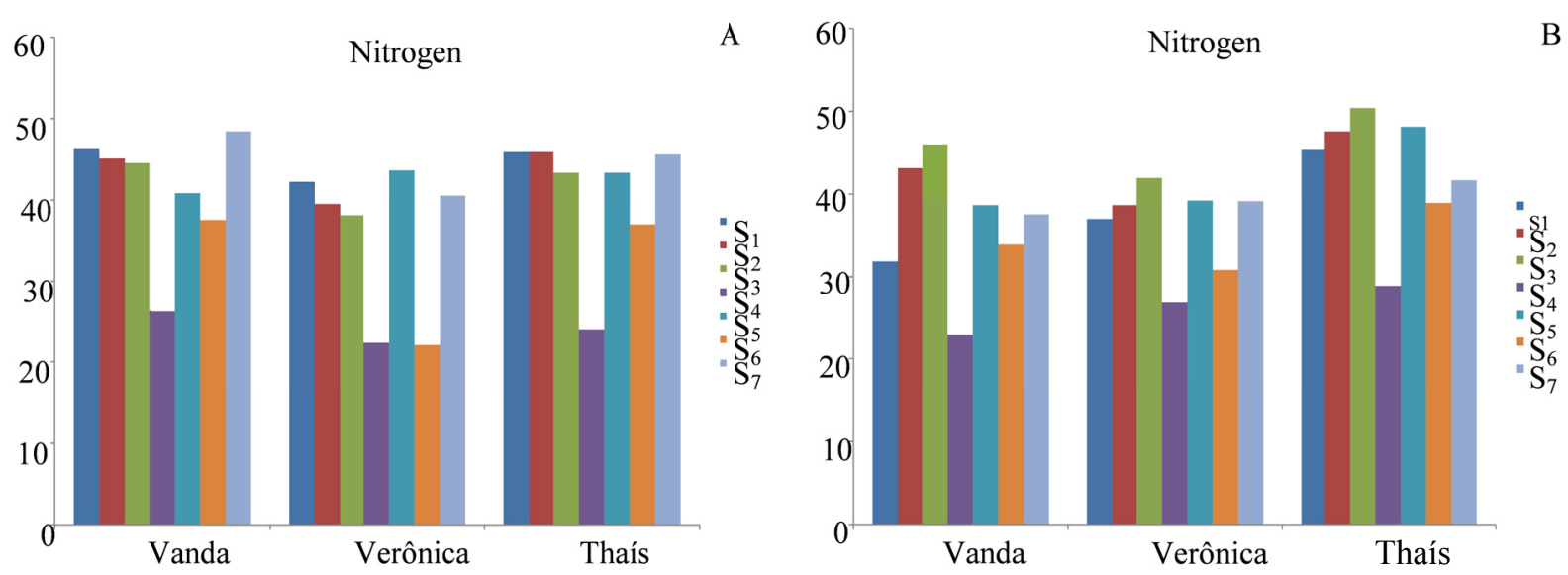

Figure 1. Shoot Mineral nitrogen composition $\left(\mathrm{g} \mathrm{kg}^{-1}\right)$ of the curly lettuce of the first (A) and second experiment

(B) in hydroponic conditions. $\mathrm{S}_{1}=$ Furlani solution; $\mathrm{S}_{2}=$ domestic wastewater; $\mathrm{S}_{3}=$ optimized domestic wastewater; $\mathrm{S}_{4}=$ well water; $\mathrm{S}_{5}=$ optimized well water; $\mathrm{S}_{6}=$ wastewater solution from the UASB reactor and $\mathrm{S}_{7}$ = wastewater solution from the optimized UASB reactor

The highest total nitrogen content found in the cultivars of curly lettuce was in the Vanda cultivar with the S7 solution, whose content was $48.47 \mathrm{~g} \mathrm{~kg}^{-1}$ (Figure 1A).

The highest levels of nitrogen were found in the cultivars Thaís, Vanda and Verônica both in the $\mathrm{S}_{3}$ solution with $50.44,45.95,42.03\left(\mathrm{~g} \mathrm{~kg}^{-1}\right)$ respectively (Figure 1B). These values are considered adequate for lettuce, according to Trani and Raij (1997) the limits are from 30 to $50 \mathrm{~g} \mathrm{~kg}^{-1}$.
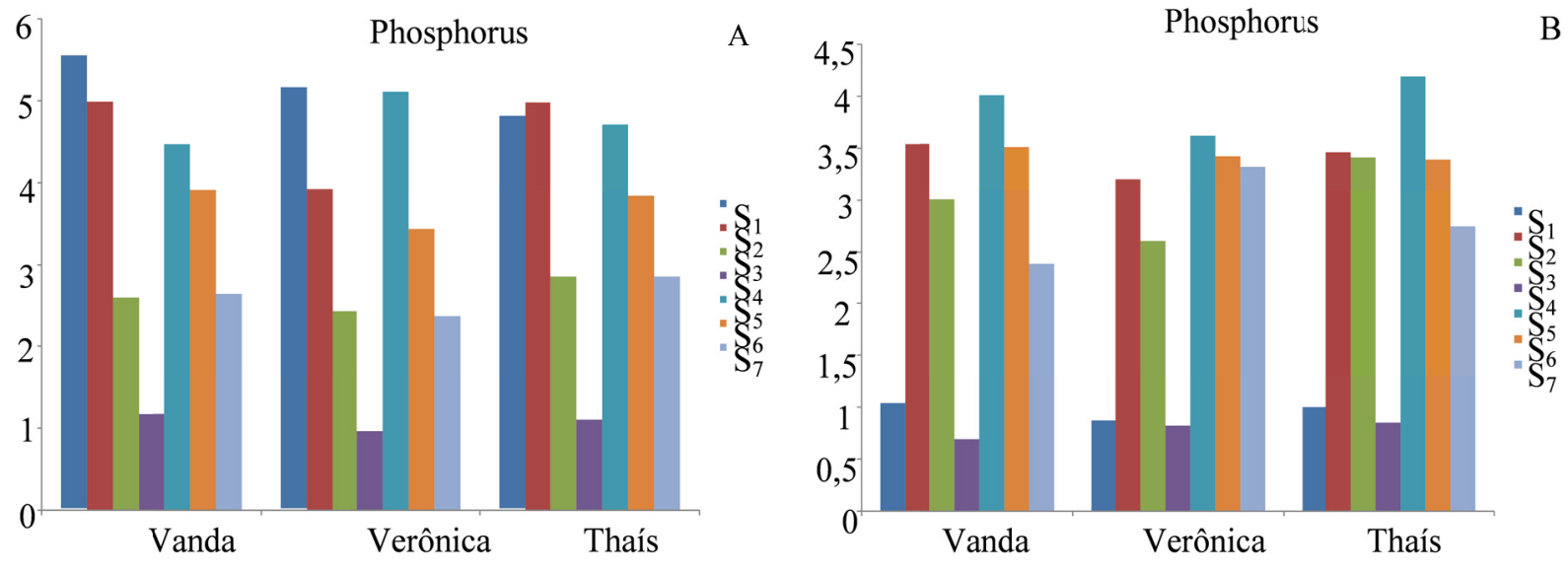

Figure 2. Mineral phosphorus composition $\left(\mathrm{g} \mathrm{kg}^{-1}\right)$ of the aerial part of the curly lettuce prepared according to the treatments and repetitions at the end of the first (A) and second experiment (B) of the hydroponic culture respectively. $\mathrm{S}_{1}=$ Furlani solution; $\mathrm{S}_{2}=$ domestic wastewater; $\mathrm{S}_{3}=$ optimized domestic wastewater; $\mathrm{S}_{4}=$ well water; $\mathrm{S}_{5}=$ optimized well water; $\mathrm{S}_{6}=$ wastewater solution from the UASB reactor and $\mathrm{S}_{7}=$ wastewater solution from the optimized UASB reactor

The highest phosphorus content found was $5.53 \mathrm{~g} \mathrm{~kg}^{-1}$ was in the Vanda cultivar with the $\mathrm{S}_{1}$ solution (Figure 2A). Iit can be seen that the highest found phosphorus value was $4.19\left(\mathrm{~g} \mathrm{~kg}^{-1}\right)$ in the cultivar Thaís $\mathrm{S}_{5}$ solution (Figure 2B). For the phosphorus content, in all treatments, it presented adequate levels for the lettuce, as described by Trani and Raij (1997), which is from 4.0 to $7.0 \mathrm{~g} \mathrm{~kg}^{-1}$. 

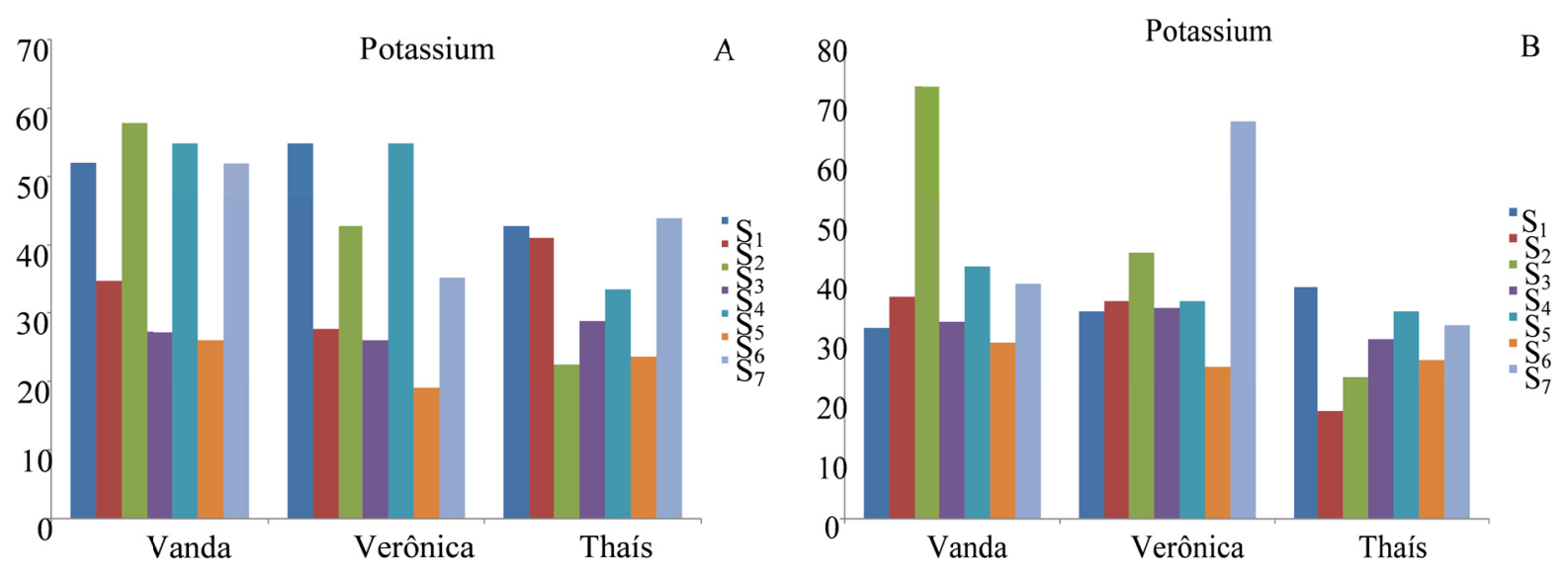

Figure 3. Potassium mineral composition $\left(\mathrm{g} \mathrm{kg}^{-1}\right)$ of the aerial part of the curly lettuce prepared according to the treatments and repetitions at the end of the first (A) and second experiment (B) of the hydroponic cultivation $\mathrm{S}_{1}$

$=$ Furlani solution; $\mathrm{S}_{2}=$ domestic wastewater; $\mathrm{S}_{3}=$ optimized domestic wastewater; $\mathrm{S}_{4}=$ well water; $\mathrm{S}_{5}=$ optimized well water; $\mathrm{S}_{6}=$ wastewater solution from the UASB reactor and $\mathrm{S}_{7}=$ wastewater solution from the optimized UASB reactor

The highest potassium contents found with concentrations of $54.91 \mathrm{~g} \mathrm{~kg}^{-1}$ were in Vanda cultivars with solution $\mathrm{S}_{5}$ and Verônica in solutions $\mathrm{S}_{1}$ and $\mathrm{S}_{5}$ (Figure $3 \mathrm{~A}$ ). It is verified that in Vanda cultivar with solution $\mathrm{S}_{3}$ the potassium content found was 72.50 and in Veronica $S_{7}$ of $66.70 \mathrm{~g} \mathrm{~kg}^{-1}$ (Figure 4B). These results corroborate with those found by Sandri et al. (2007). Alvarenga et al. (2003), which found potassium levels lower than the results found in this research.
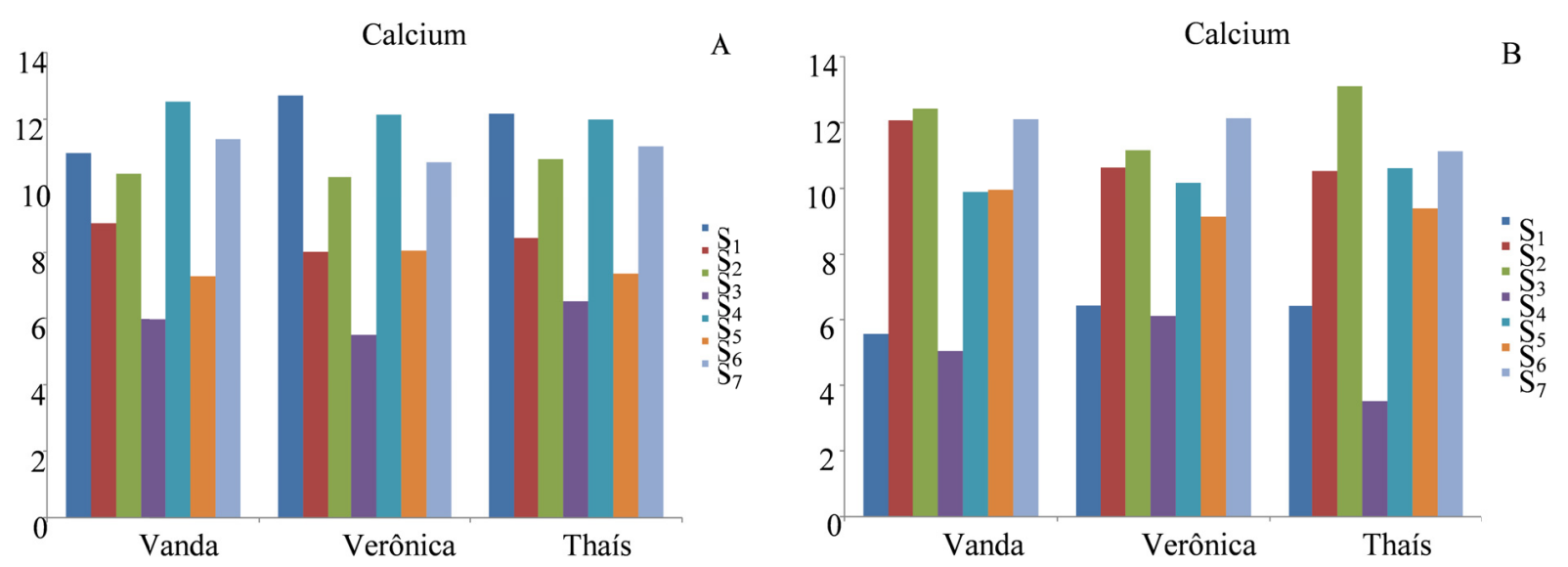

Figure 4. Calcium mineral composition $\left(\mathrm{g} \mathrm{kg}^{-1}\right)$ of the aerial part of the curly lettuce prepared as a function of the treatments and repetitions at the end of the first (A) and second experiment (B) of the hydroponic culture respectively. $\mathrm{S}_{1}=$ Furlani solution; $\mathrm{S}_{2}=$ domestic wastewater; $\mathrm{S}_{3}=$ optimized domestic wastewater; $\mathrm{S}_{4}=$ well water; $\mathrm{S}_{5}=$ optimized well water; $\mathrm{S}_{6}=$ wastewater solution from the UASB reactor and $\mathrm{S}_{7}=$ wastewater solution from the optimized UASB reactor

According to the analysis of the shoot of the cultivars of curly lettuce, it can be observed that the highest calcium contents were found in the cultivar Verônica cultivars with the $S_{1}$ solutions $12.71 \mathrm{~g} \mathrm{~kg}^{-1}$ and $S_{5} 12.14 \mathrm{~g} \mathrm{~kg}^{-1}$ and to Vanda in the solution $S_{5} 12.52 \mathrm{~g} \mathrm{~kg}^{-1}$ (Figure 4A). The highest calcium content $13.10 \mathrm{~g} \mathrm{~kg}^{-1}$ was to cultivate Thaís with solution $\mathrm{S}_{3}$, it was also verified that the cultivar Vanda $\mathrm{S}_{5}$ presented content of $12.42 \mathrm{~g} \mathrm{~kg}^{-1}$ (Figure 4B). In all treatments, the levels were adequate for well-nourished plants, which, according to Trani and Raij (1997), are usually up to $15 \mathrm{~g} \mathrm{~kg}^{-1}$. 

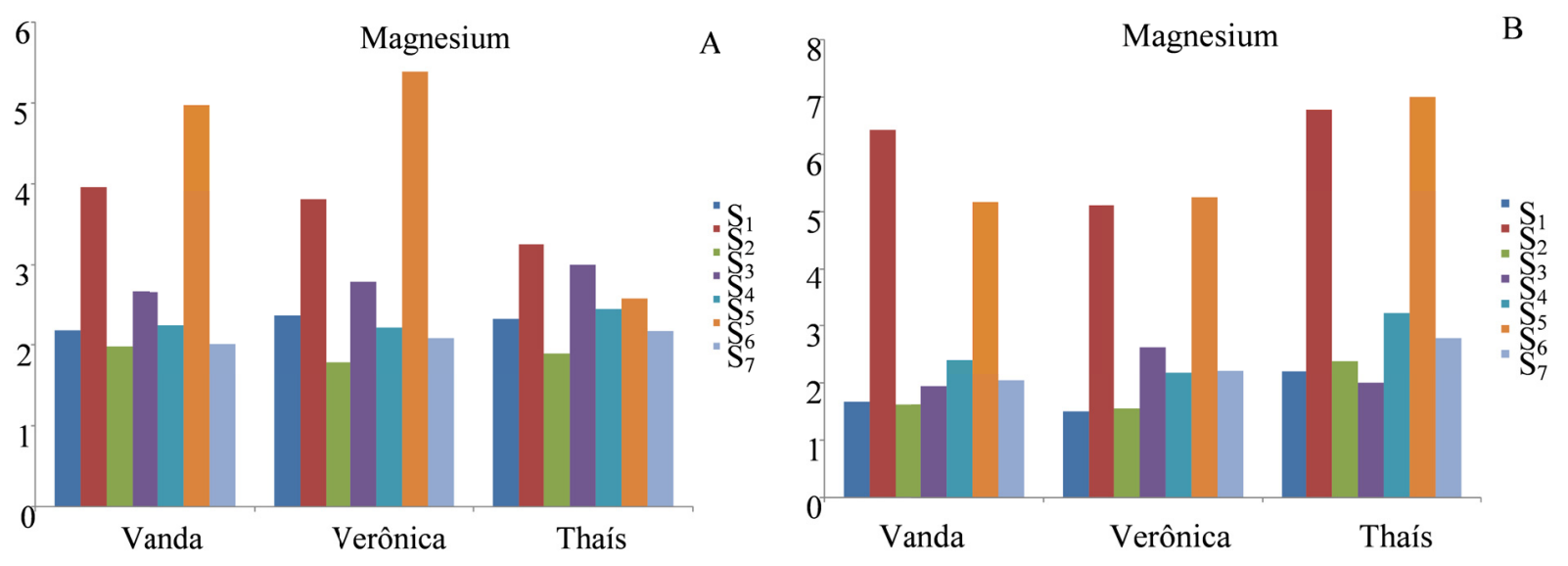

Figure 5. Magnesium mineral composition $\left(\mathrm{g} \mathrm{kg}^{-1}\right)$ of the aerial part of the curly lettuce prepared according to the treatments and repetitions at the end of the first (A) and second experiment (B) of the hydroponic culture respectively. $\mathrm{S}_{1}=$ Furlani solution; $\mathrm{S}_{2}=$ domestic wastewater; $\mathrm{S}_{3}=$ optimized domestic wastewater; $\mathrm{S}_{4}=$ well water; $\mathrm{S}_{5}=$ optimized well water; $\mathrm{S}_{6}=$ wastewater solution from the UASB reactor and $\mathrm{S}_{7}=$ wastewater solution from the optimized UASB reactor

It is observed that the highest magnesium contents were obtained in the cultivar Veronica cultivars with the $\mathrm{S}_{6}$ solution $5.39 \mathrm{~g} \mathrm{~kg}^{-1}$ and Vanda in $\mathrm{S}_{6} 4.98 \mathrm{~g} \mathrm{~kg}^{-1}$ (Figure 5A). It can be seen that the highest levels of magnesium were found in cultivar Thaís $S_{6}$ with $7.01 \mathrm{~g} \mathrm{~kg}^{-1}$ and in Vanda $S_{2}$ with $6.43 \mathrm{~g} \mathrm{~kg}^{-1}$ (Figure 5B) These contents are adequate for the lettuce according to the data presented by Trani and Raij (1997), which recommend to be between 4.0 and $6.0 \mathrm{~g} \mathrm{~kg}^{-1}$, except for cultivar Thaís $\mathrm{S}_{6}$.
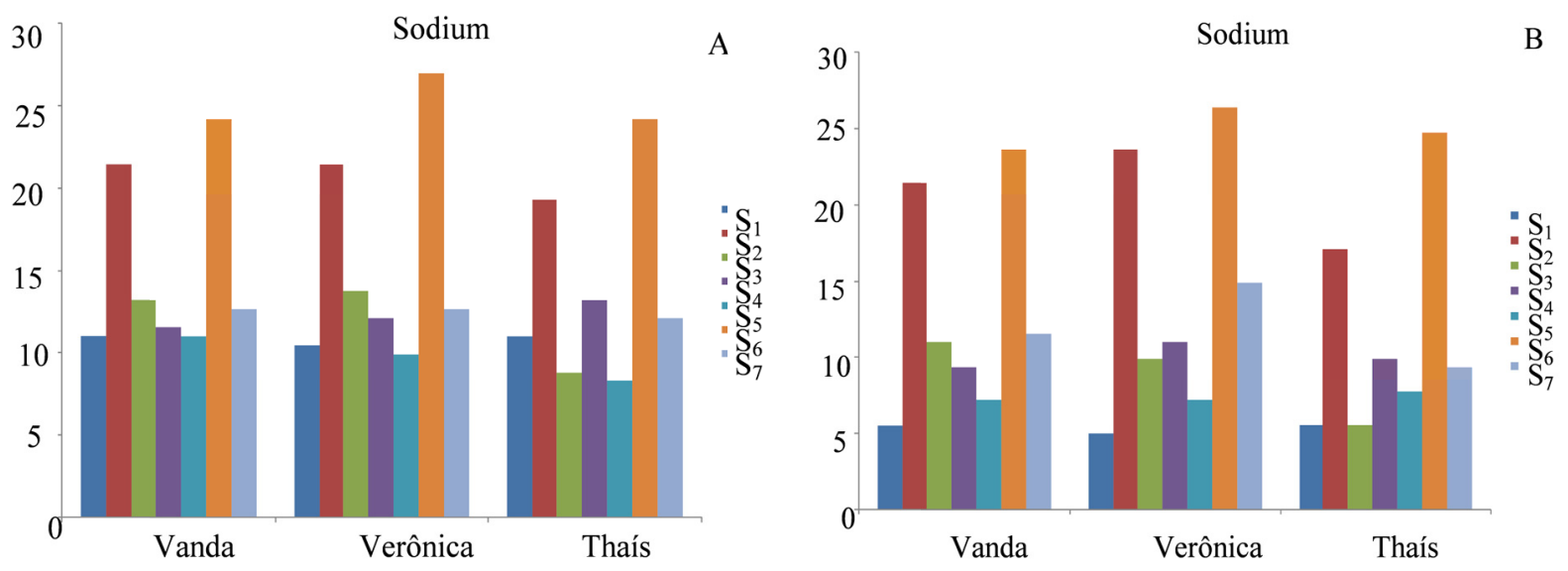

Figure 6. Sodium mineral composition $\left(\mathrm{g} \mathrm{kg}^{-1}\right)$ of the aerial part of the crisp lettuce prepared according to the treatments and repetitions at the end of the first (A) and second experiment $(\mathrm{B})$ of the hydroponic culture respectively. $\mathrm{S}_{1}=$ Furlani solution; $\mathrm{S}_{2}=$ domestic wastewater; $\mathrm{S}_{3}=$ optimized domestic wastewater; $\mathrm{S}_{4}=$ well water; $\mathrm{S}_{5}=$ optimized well water; $\mathrm{S}_{6}=$ wastewater solution from the UASB reactor and $\mathrm{S}_{7}=$ wastewater solution from the optimized UASB reactor

The sodium content found in the aerial part of the lettuce, was $26.95 \mathrm{mg} \mathrm{kg}^{-1}$ in the cultivar Verônica irrigated with the solution $\mathrm{S}_{6}$ (Figure 6A). When analyzing is observed that cultivar Vanda showed the highest sodium content of $26.40 \mathrm{mg} \mathrm{kg}^{-1}$ in the solution $\mathrm{S}_{6}$ (Figure 6B). This behavior is inherent in lettuce plants, which have great ability to retain this ion in their tissues. The sodium content observed was associated to its concentration in the wastewater, probably the most responsible in all types of irrigation, due to the application of the wastewater. 

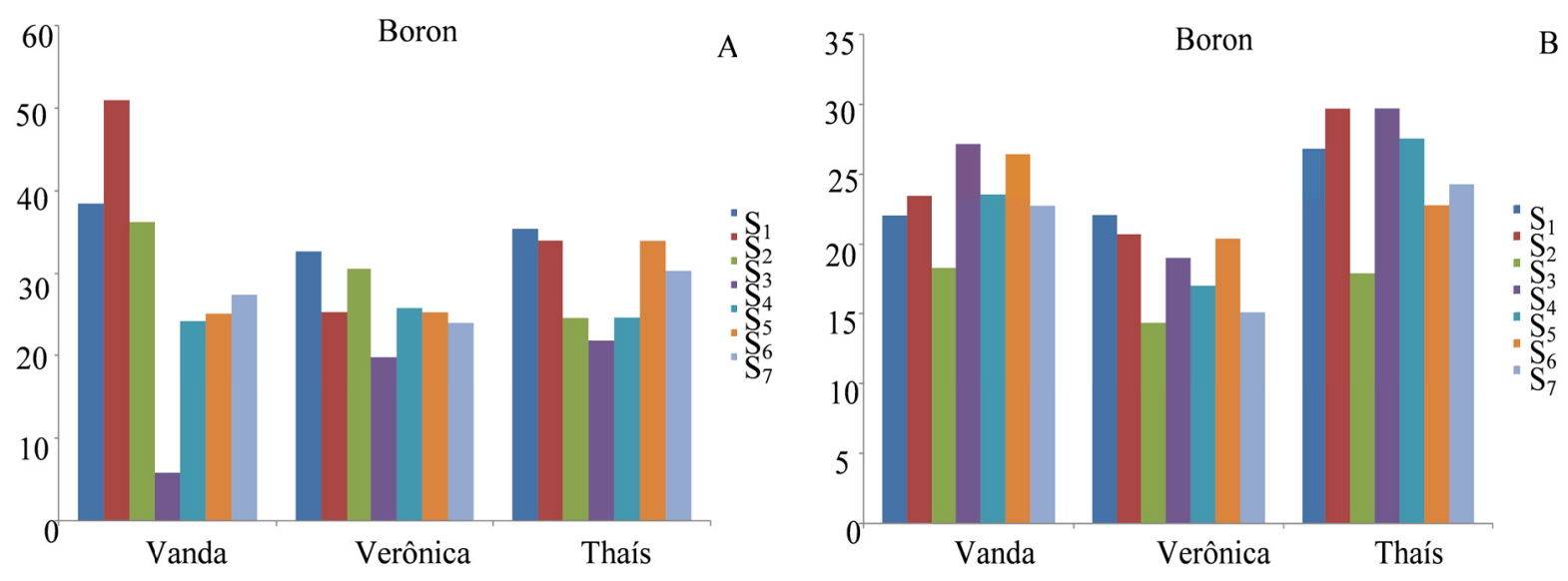

Figure 7. Boron mineral composition $\left(\mathrm{mg} \mathrm{kg}^{-1}\right)$ of the aerial part of the curly lettuce prepared as a function of the treatments and repetitions at the end of the first (A) and second experiment (B) of the hydroponic culture respectively. $\mathrm{S}_{1}=$ Furlani solution; $\mathrm{S}_{2}=$ domestic wastewater; $\mathrm{S}_{3}=$ optimized domestic wastewater; $\mathrm{S}_{4}=$ well water; $\mathrm{S}_{5}=$ optimized well water; $\mathrm{S}_{6}=$ wastewater solution from the UASB reactor and $\mathrm{S}_{7}=$ wastewater solution from the optimized UASB reactor

It was observed that the highest boron content was $50.97 \mathrm{mg} \mathrm{kg}^{-1}$, to cultivar Vanda with the solution $\mathrm{S}_{2}$ (Figure 7A). The boron content was 29.74 and $29.72 \mathrm{mg} \mathrm{kg}^{-1}$, for the cultivar Thaís irrigated with the solutions $\mathrm{S}_{4} \mathrm{e}_{2}$ (Figure 7B). The boron levels are within the standards recommended by Trani and Raij (1997) and Sanches et al. (1991) that in the leaves of lettuce, are quite broad, varying between 20 and $60 \mathrm{mg} \mathrm{kg}{ }^{-1}$. This broad range described by the authors is basically due to the same factors, especially the wastewater, which may contain high concentrations of boron when there is contribution of effluents with the presence of cleaning material, which is the case of the wastewater used in this research.
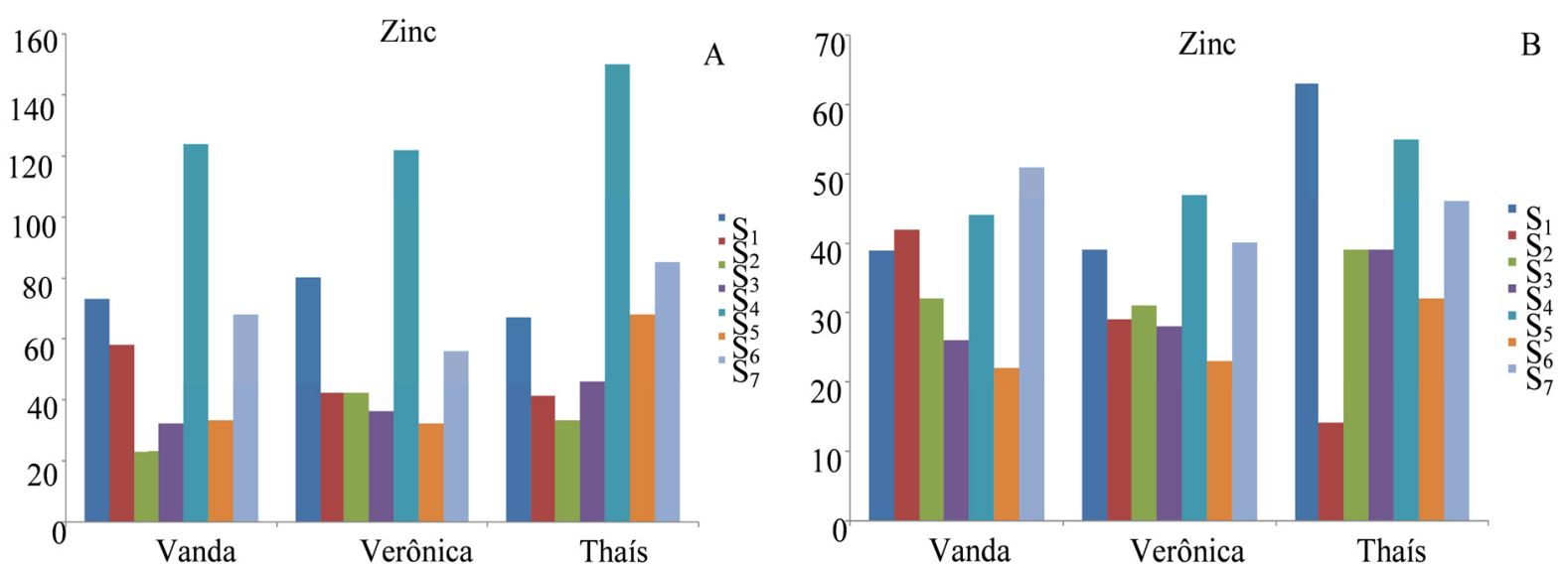

Figure 8. Zinc mineral composition $\left(\mathrm{mg} \mathrm{kg}^{-1}\right)$ of the aerial part of the curly lettuce prepared as a function of the treatments and repetitions at the end of the first (A) and second experiment (B) of the hydroponic culture respectively. $\mathrm{S}_{1}=$ Furlani solution; $\mathrm{S}_{2}=$ domestic wastewater; $\mathrm{S}_{3}=$ optimized domestic wastewater; $\mathrm{S}_{4}=$ well water; $\mathrm{S}_{5}=$ optimized well water; $\mathrm{S}_{6}=$ wastewater solution from the UASB reactor and $\mathrm{S}_{7}=$ wastewater solution from the optimized UASB reactor

In all analyzes of the cultivars of lettuces showed concentrations of zinc within the values suitable for the culture. The highest zinc content was $150 \mathrm{mg} \mathrm{kg}^{-1}$ in the cultivar Thaís irrigated with the solution $\mathrm{S}_{5}$ this value is at the recommended maximum limit, which is from 30 to $150 \mathrm{mg} \mathrm{kg}^{-1}$, suggested by Boareto et al. (Figure 8A). (1999). The results shows that zinc presented the highest content $63 \mathrm{mg} \mathrm{kg}^{-1}$ in the cultivar Thaís when irrigated with the solution $\mathrm{S}_{1}$ (Figure $8 \mathrm{~B}$ ). 

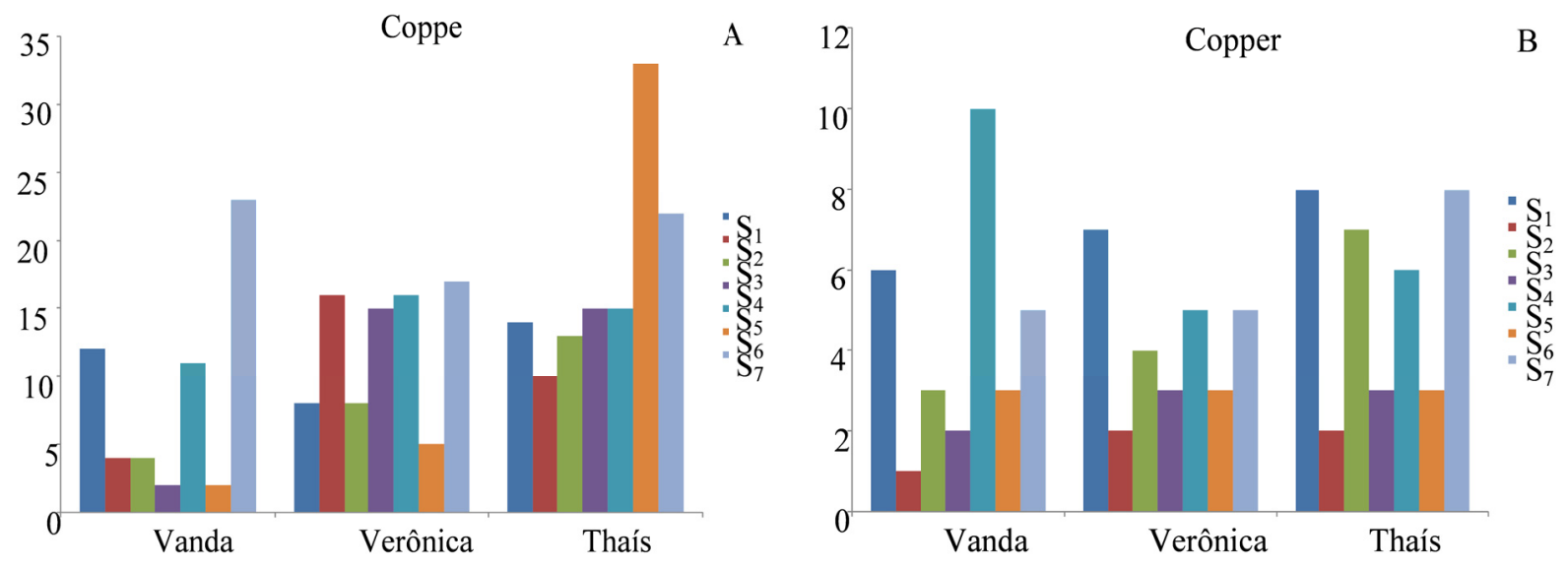

Figure 9. Copper mineral composition $\left(\mathrm{mg} \mathrm{kg}^{-1}\right)$ of the aerial part of the curly lettuce prepared according to the treatments and repetitions at the end of the first (A) and second experiment (B) of the hydroponic culture respectively. $\mathrm{S}_{1}=$ Furlani solution; $\mathrm{S}_{2}=$ domestic wastewater; $\mathrm{S}_{3}=$ optimized domestic wastewater; $\mathrm{S}_{4}=$ well water; $\mathrm{S}_{5}=$ optimized well water; $\mathrm{S}_{6}=$ wastewater solution from the UASB reactor and $\mathrm{S}_{7}=$ wastewater solution from the optimized UASB reactor

The copper content was $33 \mathrm{mg} \mathrm{kg}^{-1}$ for the cultivar Thaís when irrigated with the solution $\mathrm{S}_{6}$ (Figure 9A). The cultivar Vanda appeared to have a zinc content of $10 \mathrm{mg} \mathrm{kg}^{-1}$ when irrigated with the $\mathrm{S}_{5}$ solution (Figure 9B). Comparing the results obtained with other authors, it was verified that, according to Sanches et al. (1991) and Adams et al. (1979), the concentration obtained was above the appropriate levels for Trani and Raij (1997) and Jones Júnior et al. (1991). The variations observed between the authors can be explained by the different cultivars, climatic conditions, soil and nutrient availability in irrigation water and soil, providing or interfering negatively in the nutrients absorption by the plants.
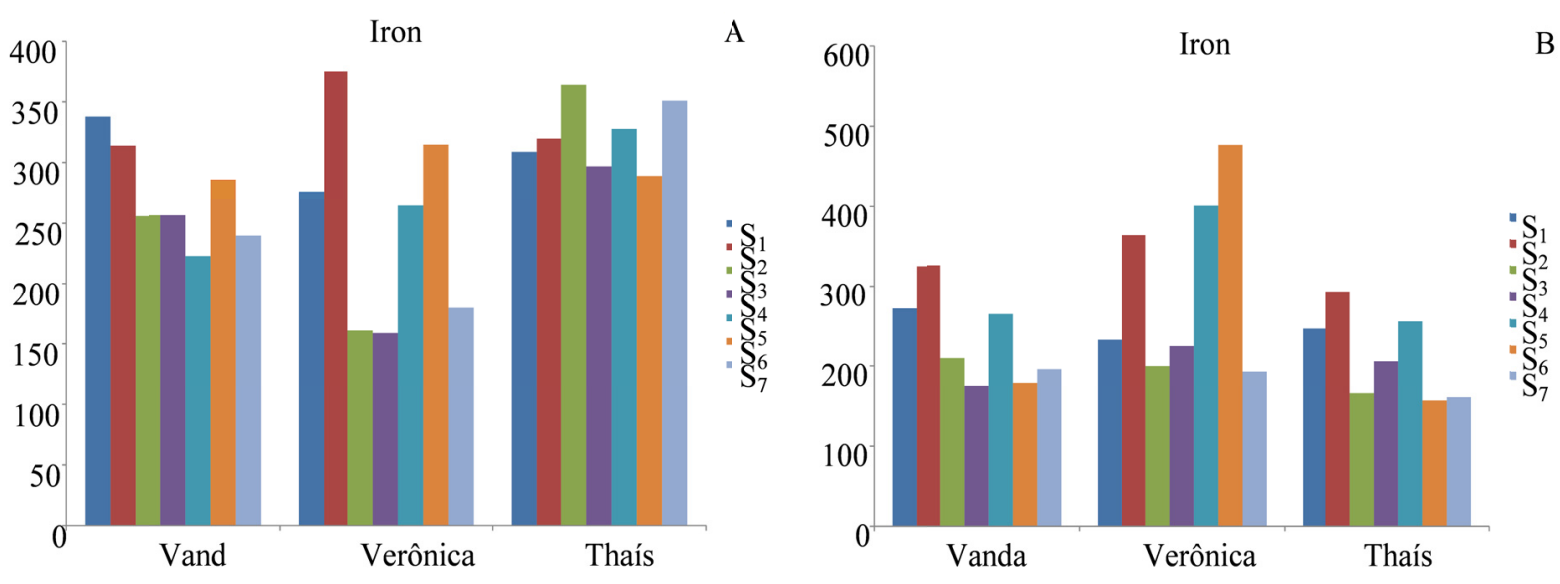

Figure 10. Iron mineral composition ( $\mathrm{mg} \mathrm{kg}^{-1}$ ) of the aerial part of the curly lettuce prepared as a function of the treatments and repetitions at the end of the first (A) and second experiment (B) of the hydroponic culture respectively. $\mathrm{S}_{1}=$ Furlani solution; $\mathrm{S}_{2}=$ domestic wastewater; $\mathrm{S}_{3}=$ optimized domestic wastewater; $\mathrm{S}_{4}=$ well water; $\mathrm{S}_{5}=$ optimized well water; $\mathrm{S}_{6}=$ wastewater solution from the UASB reactor and $\mathrm{S}_{7}=$ wastewater solution from the optimized UASB reactor

The highest iron contents found in the lettuce analyzes were 375,364 and $351 \mathrm{mg} \mathrm{kg}^{-1}$, respectively, for the Verônica cultivars with the $S_{2}$ solution, Thaís in the $S_{3}$ and $S_{7}$ solutions (Figure 10A). When analyzing the aerial part of the lettuce in the second experiment, it is observed that the iron content was $477 \mathrm{mg} \mathrm{kg}^{-1}$ for the Verônica cultivar irrigated with the $\mathrm{S}_{6}$ solution (Figure 10B). The results obtained are in the range suitable for lettuce, 
according to Sanches et al. (1991), but above the recommendations of other authors as Trani and Raij (1997), Jones Junior et al. (1991), and Adams et al. (1979).
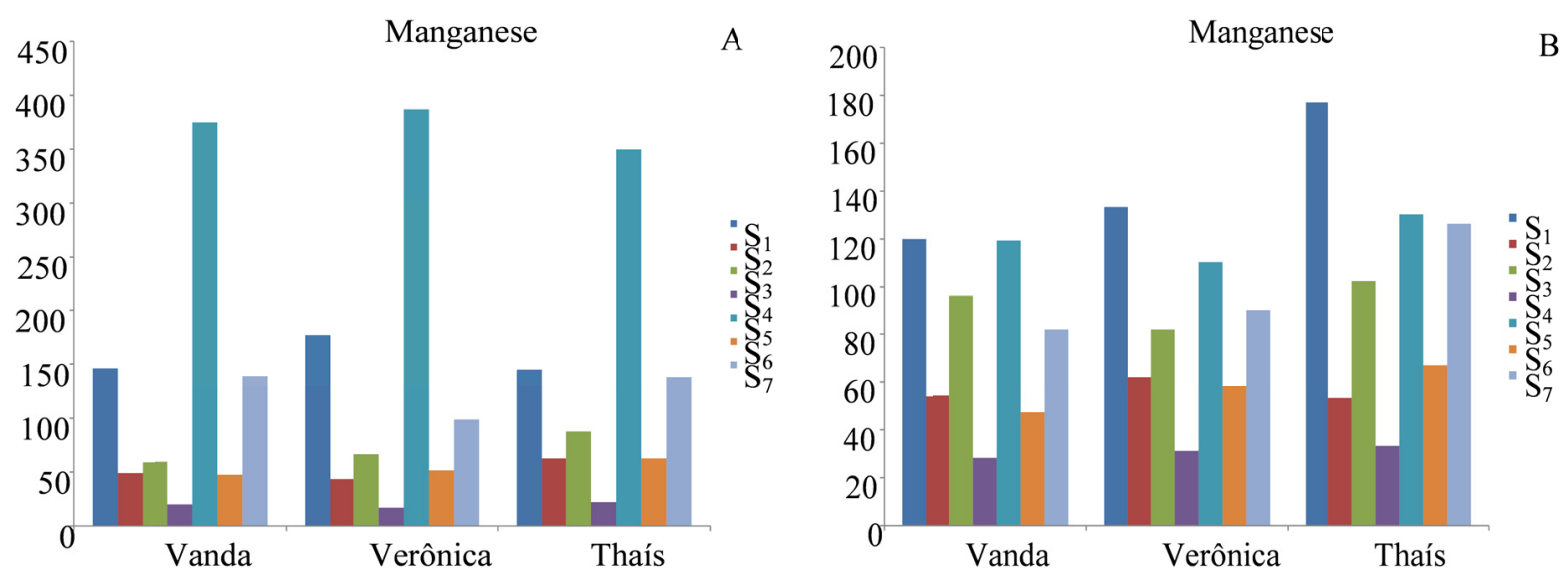

Figure 11. Manganese mineral composition $\left(\mathrm{mg} \mathrm{kg}^{-1}\right)$ of the aerial part of the curly lettuce prepared as a function of the treatments and repetitions at the end of the first $(\mathrm{A})$ and second experiment $(\mathrm{B})$ of the hydroponic culture respectively. $\mathrm{S}_{1}=$ Furlani solution; $\mathrm{S}_{2}=$ domestic wastewater; $\mathrm{S}_{3}=$ optimized domestic wastewater; $\mathrm{S}_{4}=$ well water; $\mathrm{S}_{5}=$ optimized well water; $\mathrm{S}_{6}=$ wastewater solution from the UASB reactor and $\mathrm{S}_{7}=$ wastewater solution from the optimized UASB reactor

Manganese, an element that actively participates in photosynthesis and nitrate reduction, increases the resistance of plants to some diseases. It is verified that the manganese contents presented high concentrations in the cultivars Verônica 387, Vanda 375 and Thaís $350 \mathrm{mg} \mathrm{kg}^{-1}$ respectively (Figure 11A), both irrigated with solution $\mathrm{S}_{5}$. For the analysis performed in experiment II, it can be seen in that the manganese content of $177 \mathrm{mg} \mathrm{kg}^{-1} \mathrm{was}$ found in the cultivar Thaís irrigated by Furlani solution $\left(\mathrm{S}_{1}\right)$ (Figure 11B). These levels are above the recommended range for lettuce, which is 30 to $150 \mathrm{mg} \mathrm{kg}^{-1}$ Boareto et al., (1999).

\section{Conclusion}

(1) It was verified that the treatments $S_{2}, S_{4}$ and $S_{6}$ when compared with the respective optimized solutions $S_{3}$, $S_{5}$ and $S_{7}$ presented lower levels of nitrogen, potassium, calcium, zinc, copper and manganese in the two experiments. Same behavior was not observed for phosphorus and sodium.

(2) Optimized solution of the raw sewage $\left(\mathrm{S}_{3}\right)$ and optimized solution of Extrabes $\left(\mathrm{S}_{7}\right)$ promoted, for most of the analyzed minerals, values close to those obtained with the Furlani mineral solution, independently of the cultivar and the experiment analyzed, and may be a viable alternative for semi-arid farmers.

(3) As for the cultivars, they presented, regardless of the experiment, mineral composition similar to each other when the same nutrient solution was used.

\section{References}

Adams, P., Graves, C. J., \& Windson, G. W. (1979). Effects of copper deficiency and liming on the yield, quality and copper status of tomatoes, lettuce, and cucumber grown in peat. Scientia Horticultural, 9(3), 199-205. https://doi.org/10.1016/0304-4238(78)90001-8

Alvarenga, M. A. R., Silva, E. C. da, Souza, R. J., \& Carvalho, J. G. (2003). Teores e acúmulo de macronutrientes em alface americana, em função da aplicação de nitrogênio no solo e de cálcio via foliar. Ciência Agrotécnica, 27, 1569-75. https://doi.org/10.1590/S0100-69162006000100006

Andrade Filho, J., Sousa Neto, O. N. de, Dias, N. da S., Nascimento, I. B., Medeiros, J. F. de, \& Cosme, C. R. (2013). Atributos químicos de solo fertirrigado com água residuária no semiárido brasileiro. Revista Irriga, 18(4), 661-674. https://doi.org/10.15809/irriga.2013v18n4p661

Boareto, A. E., Chitolina, J. C., Raij, B. V., Silva, F. C., Tedesco, M. J., \& Carmo, C. A. F. S. (1999). Amostragem, acondicionamento e preparação das amostras de plantas para análise química. In F. C. Silva (Ed.), Manual de análises químicas de solos, plantas e fertilizantes (pp. 49-73). Brasília: Embrapa Solos. 
Bonini, M. A., Sato, L. M., Bastos, R. G., \& Souza, C. F. (2014). Alterações nos atributos químico e físicos de um Latossolo Vermelho irrigado com água residuária e vinhaça. Revista Biociências, 20, 56-63.

Carr, G., Potter, R. B., \& Nortcliff, S. (2011). Water reuse for irrigation in Jordan: Perceptions of water quality among farmers. Agric. Water Manage, 98(5), 847-854. https://doi.org/10.1016/j.agwat.2010.12.011

Correia, E. C. S. (2013). Reação de cultivares de alface do grupo americano a Meloidoygine incognita, M. javanica e M. enterolobii (55f. Dissertação (Mestrado em Agronomia), Universidade Estadual Paulista "Júlio de Mesquita Filho", Botucatu, Brazil).

Embrapa (Empresa Brasileira de Pesquisa Agropecuária). (2009). Manual de análises químicas de solos, plantas e fertilizantes/editor técnico, Fábio Cesar da Silva (2nd ed.). Brasília, DF: Embrapa Informação Tecnológica.

Furlani, P. R., Bolonhezi, D., Silveira, L. C. P., \& Faquin, V. (1999). Nutrição mineral de hortaliças, preparo e manejo de soluções nutritivas. Informe Agropecuário, 20(200/201), 90-98.

Hanjraa M. A., Blackwell J., Carrc G., Zhang F., \& Jackson T. M. (2012). Wastewater irrigation and environmental health: Implications for water governance and public policy. International Journal of Hygiene and Environmental Health, 215, 255-269. https://doi.org/10.1016/j.ijheh.2011.10.003

Jones Junior., J. B., Wolf, B., \& Mills, H. A. (1991). Appendix 1: Table of interpretative values: Vegetables. Plant analysis handbook (pp. 177-187). Athens: MicroMacro Publ.

Lopes, C. A., Duval, A. M. Q., \& Reis, A. (2010). Doenças da alface (p. 68). Brasília: Embrapa Hortaliças.

Martínez, S., Suay, R., Moreno, J., \& Segura, M. L. (2013). Reuse of tertiary municipal wastewater effluent for irrigation of Cucumis melo L. Irrigation Science, 31, 661-672. https://doi.org/10.1007/s00271-012-0342-4

Matos, A. T., Silva, D. F., Lo Monaco, P. A. V., \& Pereira, O. G. (2013). Produtividade e composição química do capim tifton 85 submetido a diferentes taxas de aplicação do percolado de resíduo sólido urbano. Revista Engenharia Agrícola, 33(1), 188-200. https://doi.org/10.1590/S0100-69162013000100019

Monteiro Filho, A. F., Pereira, G. L., Azevedo, M. R. Q. de A., Fernandes, J. D., \& Azevedo, C. A. V. de. (2014). Cultivo hidropônico de cultivares de alface em soluções nutritivas organominerais otimizadas com a ferramenta Solver. Revista Brasileira de Engenharia Agrícola e Ambiental, 18, 417-424. https://doi.org/ 10.1590/S1415-43662014000400009

Oliveira, P. C. P., V. Gloaguen, T. V., Gonçalves, R. A. B., \& Santos, D. L. (2013b). Produção de moranga irrigada com esgoto doméstico tratado. Revista Brasileira de Engenharia Agrícola Ambiental, 17(8), 861-867. https://doi.org/10.1590/S1415-43662013000800010

Ribeiro, M., Lima, L., Faria, F. H. S., Rezende, F. C., \& Faria, L. A. (2009). Efeitos de águas residuárias de café no crescimento vegetativo de cafeeiros em seu primeiro ano. Engenharia Agrícola, Jaboticabal, 29(4), 569-577. https://doi.org/10.1590/S0100-69162009000400007

Sala, F. C., \& Costa, C. P. (2012). Retrospectiva e tendência da alfacicultura brasileira. Revista Horticultura Brasileira, 30, 187-194. https://doi.org/10.1590/S0102-05362012000200002

Sanchez, C. A., Snyder, G. H., \& Burdine, H. W. (1991). Dris evaluation of nutricional status of crisphead lettuce. Horticultura. Science, 26(3), 274-6.

Sandri, D., Matsura, E. E., \& Testezlaf, R. (2007). Desenvolvimento da alface Elisa em diferentes sistemas de irrigação com água residuária. Revista Brasileira de Engenharia Agrícola e Ambiental, 11(1), 17-29. https://doi.org/10.1590/S1415-43662007000100003

Santos, R. S. S., Dias, N. S., Duarte, S. N., \& Lima, C. J. G. S. (2012). Uso de águas salobras na produção de rúcula cultivada em substrato de fibra de coco. Revista Caatinga, 25, 113-118.

Schaer Barbosa, M., Santos, M. E. P., \& Medeiros, Y. D. P. (2014). Viabilidade do reuso de água como elemento mitigador dos efeitos da seca no semiárido da Bahia. Revista Ambiente \& Sociedade, 2, 17-32. https://doi.org/10.1590/S1414-753X2014000200003

Sousa, T. P. de, Souza Neto, E. P., Silveira, L. R. de S., Santos Filho, E. F. dos, \& Maracajá, P. B. (2014). Produção de alface (Lactuca sativa L.), em função de diferentes concentrações e tipos de biofertilizantes. Revista Verde de Agroecologia e Desenvolvimento Sustentável, 9(4), 168-172.

Trani, P. E., \& Raij, B. van. (1997). Hortaliças. Boletim Técnico do Instituto Agronômico, 100, 30-36. 
Varallo, A. C. T., Souza, C. F., \& Santoro, B. de L. (2012). Mudanças nas características físico-químicas de um latossolo vermelho-amarelo distrófico após a irrigação com água de reuso na cultura da alface-crespa (Lactuca sativa L.). Engenharia Agrícola, 32(2), 271-279. https://doi.org/10.1590/S0100-69162012000 200007

\section{Copyrights}

Copyright for this article is retained by the author(s), with first publication rights granted to the journal.

This is an open-access article distributed under the terms and conditions of the Creative Commons Attribution license (http://creativecommons.org/licenses/by/4.0/). 